\title{
Involvement of Nitric Oxide and Its Up/Down Stream Molecules in the Immunity Against Parasitic Infections
}

\author{
Hossein Nahrevanian \\ Department of Parasitology, Pasteur Institute of Iran, Tehran, Iran
}

\begin{abstract}
Nitric oxide (NO) is a potent mediator with diverse roles in regulating cellular functions and signaling pathways. The NO synthase (NOS) enzyme family consists of three major isoforms, which convey variety of messages between cells, including signals for vasorelaxation, neurotransmission and cytotoxicity. This family of enzymes are generally classified as neuronal NOS (nNOS), endothelial NOS (eNOS) and inducible NOS (iNOS). Increased levels of NO are induced from iNOS during infection; while eNOS and nNOS may be produced at the baseline in normal conditions. An association of some key cytokines appears to be essential for NOS gene regulation in the immunity of infections. Accumulating evidence indicates that parasitic diseases are commonly associated with elevated production of NO. NO plays a role in the immunoregulation and it is implicated in the host non-specific defence in a variety of infections. Nevertheless, the functional role of NO and NOS isoforms in the immune responses of host against the majority of parasites is still highly controversial. In the present review, the role of parasitic infections will be discussed in the controversy related to the NO production and iNOS gene expression in different parasites and a variety of experimental models.

Key-Words: iNOS, nitric oxide, NO, immunity, helminth, parasite, Protozoa.
\end{abstract}

The nitric oxide (NO) molecule consists of oxygen and nitrogen atoms, bound by a double bond [1]. NO is a product of L-arginine conversion to L-citrulline by nitric oxide synthase (NOS) enzyme in the presence of nicotinamide adenine dinucleotide phosphate (NADPH) as a co-factor (Figure 1.). $\mathrm{NO}$ is a reactive free radical, and in the presence of oxygen, is oxidised to a variety of nitrogen oxides [2]. NO is known to react rapidly with oxyhemoglobin $(\mathrm{O} x y-\mathrm{Hb})$ to give nitrate and met-Hb [3]. It has recently been found to be a potent immuno-modulator, which has alternative roles during inflammation, infection and transplant rejection [4]. Both oxygen and NO are vital for life processes, but too much of either can damage cells. It is suggested the attachment of NO to proteins enable them to activate gene(s) directly, but the body needs to keep NO in equilibrium by turning on and off expression of NO gene(s). NO also has an extraordinary physiological role with an ability to diffuse freely through cell membranes offering a new perspective on cell-cell communication [5].

Potential effector mechanisms of immunity against parasitic infections include antibodies, macrophages, T-cells, cytokines and a variety of other soluble mediators. Activated phagocytic cells generate large amounts of highly toxic molecules, reactive nitrogen and oxygen intermediate (RNI, ROI), $\mathrm{H}_{2} \mathrm{O}_{2}$, NO and many cytokines and enzymes [6-8]. NO reacts to form biologically active oxides, which react in several ways. In addition to numerous cytokines, the role of $\mathrm{NO}$ as a mediator in clinical parasitic diseases remains controversial.

Received on 12 April 2009; revised 6 July 2009.

Address for correspondence: Dr. H. Nahrevanian, Department of Parasitology. Pasteur Institute of Iran, Pasteur Ave., Tehran 13164, Iran. E-mail: mobcghn@pasteur.ac.ir, mobcghn@yahoo.co.uk. Phone / Fax: +98-21-66968855.

The Brazilian Journal of Infectious Diseases 2009;13(6):440-448. (C) 2009 by The Brazilian Journal of Infectious Diseases and Contexto Publishing. All rights reserved.
Figure 1. Nitric oxide production by three nitric oxide synthase isoforms. NADPH, nicotinamide adenine dinucleotide phosphate hydrogenase; NADP, nicotinamide adenine dinucleotide phosphate.

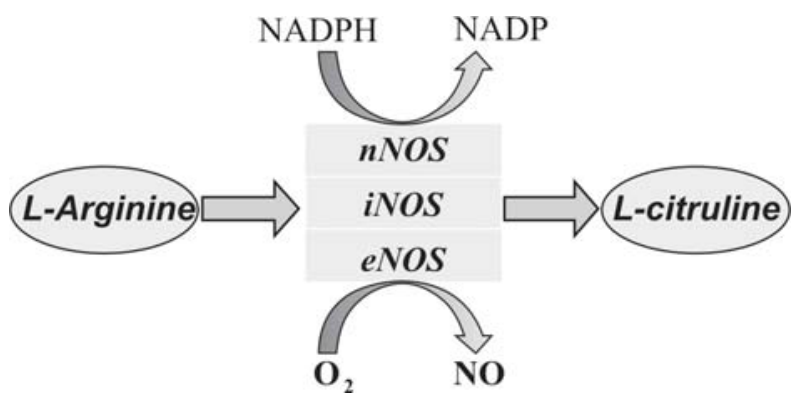

In previous reports, NO, RNI and NOS involvement in parasitic infections were investigated; however, variation in NO levels and NOS activities is under debate [9-11].

\section{Immune Cell Types in NO Involvement During Infections}

NO is produced by many cell types to induce many functions [12,13]. As part of the cytotoxic function, a variety of cells is involved in NO production including macrophages, neutrophils, Kupffer cells, lymphocytes and hepatocytes that are stimulated to produce RNI and ROI by some key cytokines such as TNF- $\alpha$ and IFN- $\gamma[14,15]$. NOS, NO or its stable metabolites have been identified as major effector molecules. An important protective role for RNI has been established in macrophage killing of intracellular protozoa [16-19], bacteria [20,21], fungus [22] and viruses [23]. A similar role has been demonstrated in neutrophil killing of Candida albicans [24] and Staphilococcus aureus [25]. In addition, there are data showing that eosinophils are able to kill intracellular protozoan parasites [26-28]. 


\section{NOS Isoforms}

The NOS family is generally classified as constitutive, calcium dependent as neuronal NOS (nNOS), endothelial NOS (eNOS) and calcium independent inducible NOS (iNOS) [29]. The molecular masses for the three NOS enzymes are reported to be $160 \mathrm{kDa}$ (nNOS), $130 \mathrm{kDa}$ (iNOS) and $135 \mathrm{kDa}$ (eNOS) [30] (Table 1). The nNOS is constitutive with low output and mainly expressed in the central and peripheral nervous systems [29]. It normally generates low levels of NO for intracellular signalling and modulation of synaptic plasticity in the nervous system [31]. However, the overstimulated nNOS is implicated in ischemia, pain and several neurodegenerative disorders [32]. The iNOS was originally described as an enzyme that is expressed in activated macrophages, generates NO from the amino acid L-arginine and thereby contributes to the control of replication or killing of intracellular microbial pathogens [33]. It is expressed in response to endotoxins and inflammatory cytokines [32]. Inducible NOS is an inducible immune inflammatory factor with high output originally found in macrophages, hepatocytes, but later in glial cells [34]. Small quantities of iNOS-derived NO are critical for signal transduction events during infection [33]. The eNOS is also constitutive with low output [31] and mainly found in brain, neuronal tissue, neuroblastomas, skeletal muscle, vascular endothelial cells and b-cells of pancreatic islets [4]. The nNOSderived NO, relaxes the vasculature, inhibits adhesion and platelet aggregation and maintains normal blood pressure [32].

\section{Molecular Biology of NOS Isoforms}

The cDNA for the three human NOS isoforms have been cloned and characterised. The human NOS genes are located on chromosomes: 12 (nNOS), 17 (iNOS) and 7 (eNOS). In mouse they are located in different chromosomes; 5 (nNOS), 11 (iNOS) and 5 (eNOS). The human genome contains at least two loci for the iNOS gene [35], however in mouse genome one locus has been recognised for the iNOS gene [30] (Table 2).

\section{NOS Deficiency and Infections}

Experiments conducted to confirm or deny the involvement of NO and RNI in infections, using experimental NOS knockout animals have been contradictory or inconclusive [36-38]. However, it is possible that iNOS deficient mice develop alternative pathways to overcome in-born deficiencies [36,39]. The role of $\mathrm{NO}$ as a single molecule in biological processes may ultimately require a triple-knockout mouse for iNOS, eNOS and nNOS to examine this question [39].

\section{NO and Related Molecules During Infections}

A role for antiparasitic effects of NO, RNI and NOS in vivo and in vitro have been demonstrated against a number of parasites including Plasmodium sp., Leishmania sp., Toxoplasma gondeii, Schistosoma sp. and Trypanosoma brucei [15, 40, 41]. There are several experimental evidences about NO involvement in the microbicidal activity of macrophages against a number of intracellular parasitic pathogens [28] including L. major [16], T. gondii [17], T. cruzi [19], P. berghei [42], or pathogenic bacteria e.g. Mycobacterium leprae [20], fungal infections e.g. Candida albicans [22] and viral pathogens e.g. Herpes simplex [23].

\section{NO and Related Molecules During Parasitic Infections}

NOS, NO or its stable metabolites have been identified as major effector molecules during the majority of parasitic infections. It seems that $\mathrm{NO}$ is not only necessary, but is also sufficient to account for the entire antiparasitic activity [43]. There is evidence that the activated macrophages are able to kill intracellular L. major, T. gondeii and extracellular Schistosoma sp. parasites by the release of $\mathrm{NO}$ and RNI $[41,42]$. The formation of NO, RNI and ONOO- has been reported in majority of parasitic infections including Giardia lamblia, Entamoeba coli [44], L. amazonensis [45], T. gondii [46], L. mexicana [47], Schistosoma mansoni [28], Opisthorchis viverrini [48] and Clonorchis sinensis [15].

\section{NO and Related Molecules in Protozoal Infections}

Inducible NO, synthesized by the iNOS, is an antipathogen and tumoricidal agent. However, its production requires a tight control because of cytotoxic and immunemodulation activity [49]. Although there are several immunological mechanisms to eliminate the intracellular pathogens, they have elaborated a variety of strategies to escape immune response and to make possible survival and replication in the host. Several parasites are highly sensitive to $\mathrm{NO}$ and their derivatives, however some parasites modulate the production of toxic molecules [50]. Interestingly, hemoglobin, myoglobin, and neuroglobin may protect intracellular protozoa from the antiparasitic effects of NO [51]. Despite the wide evidence about anti-protozoal effects of NO, little efforts have been made to develop NO-based drugs in human medicine. This is mainly due to the difficulty in designing chemical carriers able to release the right amount of $\mathrm{NO}$, in the right place and in the right time, to avoid toxic effects against non-target host cells [49].

\section{Leishmania sp.}

NO produced by human and canine macrophages has been involved in the intracellular killing of leishmania. Mechanisms of parasite survival and persistence in the host have been thoroughly investigated, and include suppression of iNOS and the parasite entry into iNOS negative cells [49]. The iNOS expression by macrophages plays an important role during the control of leishmania infection in dogs [52], thisNO may be involved in the long-term protection of dogs against natural Leishmania infection and in the clinical presentation of canine leishmaniasis [53]. Application of potential prodrugs to cultures of infected mouse macrophages that were deficient in iNOS caused rapid death of the intracellular protozoan parasite Leishmania major with no host cell toxicity [54]. Therefore, some antileishmanial drugs act via NO modulation [55-57]. 
Table 1. Comparison of three nitric oxide synthase isoforms.

\begin{tabular}{lclll}
\hline Isoform & Protein weight $(\mathbf{K D a})$ & $\mathbf{C a}^{2+}$ dependency & Expression & \multicolumn{1}{c}{ Tissue distribution } \\
\hline nNOS & 160 & $\mathrm{Ca}^{2+}$ dependent & constitutive & Central and peripheral nervous system \\
iNOS & 130 & $\mathrm{Ca}^{2+}$ independent & inducible & Macrophage \\
eNOS & 135 & $\mathrm{Ca}^{2+}$ dependent & constitutive & Endothelial cells \\
\hline
\end{tabular}

Table 2. Chromosomal localization of nNOS, iNOS and eNOS sequences. (Mayer, 1998; Xu \& Liu, 1998).

\begin{tabular}{|c|c|c|c|c|c|c|}
\hline Name & Other names & Type & Regulated by & Present in & Human chromosome & Mouse chromosome \\
\hline nNOS & $\begin{array}{c}\text { Neuronal NOS } \\
\text { (NOS1) }\end{array}$ & Constitutive & $\mathrm{Ca}^{2+} /$ calmodulin & $\begin{array}{l}\text { Brain and } \\
\text { other tissues }\end{array}$ & $\begin{array}{c}12 \\
12 \mathrm{q} 24.1-12 \mathrm{q} 24.31\end{array}$ & $\begin{array}{c}5 \\
\text { (site } 56.0 \text { ) }\end{array}$ \\
\hline iNOS A & $\begin{array}{c}\text { Inducible NOS } \\
\text { (NOS2A) }\end{array}$ & Inducible & $\begin{array}{l}\text { Endotoxin, } \\
\text { cytokines }\end{array}$ & $\begin{array}{l}\text { Macrophages } \\
\text { Neutrophiles } \\
\text { Chondrocytes } \\
\text { Hepatocytes }\end{array}$ & $\begin{array}{c}17 \\
17 q 11.2-17 q 12\end{array}$ & $\begin{array}{c}11 \\
\text { (site } 45.6)\end{array}$ \\
\hline $\begin{array}{l}\text { iNOS B } \\
\text { iNOS C }\end{array}$ & $\begin{array}{c}\text { Inducible NOS } \\
\text { (NOS2B) } \\
\text { (NOS2C) }\end{array}$ & Unknown & Unknown & Unknown & $\begin{array}{c}17 \\
\text { 17p11.2-17q11.2 }\end{array}$ & $\begin{array}{c}11 \\
\text { (site } 45.6)\end{array}$ \\
\hline eNOS & $\begin{array}{l}\text { Endothelial } \\
\text { NOS (NOS3) }\end{array}$ & Constitutive & $\mathrm{Ca}^{2+} /$ calmodulin & $\begin{array}{l}\text { Endothelial } \\
\text { cells }\end{array}$ & $\begin{array}{c}7 \\
7 q 35-7 q 36\end{array}$ & $\begin{array}{c}5 \\
\text { (site } 9.0 \text { ) }\end{array}$ \\
\hline
\end{tabular}

Plasmodium sp.

The main control of malaria in human and animals, is achieved by NO-mediated mechanisms. Protection from severe malaria in African children has been found associated with polymorphisms of the iNOS promoter; however, a pathogenic role of endogenous $\mathrm{NO}$ has been documented in cerebral malaria [49]. There is conflicting evidence regarding the role of NO in the process of resistance against malaria parasites. Schizonts treated in vitro with NO donors caused a delayed infection to mice in a dose and time-dependent manner, which, suggest an inhibitory role for NO [58] with influence on parasitemia and survival of Plasmodium berghei in infected mice [59] or P. berghei Anka in rats [60]. Moreover, human severe malaria is associated with decreased NO production [61] and iNOS variants in regions of differing disease manifestation [62]. Low NO bioavailability might contribute to pathologic activation of the immune system [63] and to the experimental cerebral malaria [64]. Mechanism of NO action in malaria explain the presence of its molecules in food vacuole which is a critical parasitic compartment involved in hemoglobin degradation, heme detoxification and a target for antimalarial drug action [65]. The role of other haem enzymes including iNOS is indicated in malaria infection [66]. NO and peroxynitrite concentration is reported to be higher than hemoglobin concentration, and yet no parasite killing was detected, therefore hemoglobin protects Plasmodium parasites from oxygen radicals [67].

\section{Toxoplasma sp.}

In macrophages, Toxoplasma gondii inhibit NO production, which suggests that an iNOS suppression mechanism might be used for better survival in macrophages
[68]. Treatment of mice with a NOS inhibitor partially inhibited the host-cell apoptosis induced by the parasite infection. Apoptosis in host cells is due to the secretion of NO and other soluble factors released by parasite infected cells [69]. T. gondii has a nitrite production and a putative NOS motif genomic sequence. Recombinant protein derived from the putative genomic sequence of $T$. gondii, is able to produce nitrites [70]. In addition, NO modulates IFN- $\gamma$ production in $T$. gondii-infected mice, and that NO is involved in mediating a protective response in toxoplasmosis susceptible, but not resistant, mice strain during acute infection [71].

\section{Trypanosoma sp.}

Both intracellular and extracellular morphotypes of Trypanosoma cruzi are killed by NO in vitro and in vivo. The NO donation was shown to kill T. cruzi epimastigotes in culture. [49]. iNOS is a potent modulator of chemokine expression which is critical to triggering the generation of the inflammatory infiltrate during T. cruzi infection [72]. DNA damage and NOS activity was seen in infected mice with T. cruzi [73]. Moreover, cytokine and NO is produced by T. brucei infection in rats [74]. NO and iNOS was detected in myocardium and spleen of dogs in the acute stage of infection with metacyclic or blood trypomastigotes of $T$. cruzi [75].Immunisation with a major $T$. cruzi antigen promotes pro-inflammatory cytokines and NO production [76]. Therefore, NO may not be the sole contributor to intestinal dysfunction resulting from T. cruzi infection [77].

\section{Cryptosporidium $s p$.}

An in vivo role for peroxynitrite formation in acute mucosal defense against a noninvasive intestinal epithelial 
Cryptosporidium parvum pathogen was defined [78]. C. parvum infection revealed the location, mechanism of induction, specificity, and consequence of iNOS expression in neonatal piglets [79]. These data suggest that NO may reduce the parasite load in experimental cryptosporidiosis [80] and it is indicated that number of C. parvum oocysts in feces, proportion of CD4+, CD3+ T cells in blood, serum IFN-ã, and NO content in intestinal tissue were all higher than those of infected control group [81]. NO serves as a proximal mediator of $\mathrm{PGE}_{2}$ synthesis and barrier function in C. parvum infection [82]. Taken together these data suggest that both reactive nitrogen and reactive oxygen species play protective roles in experimental cryptosporidiosis [83].

\section{Trichomonas sp.}

NO is a macrophage-mediated cytotoxicity against Trichomonas vaginalis [84] and protozoa produce NO and display NOS activity [85]. Killing of extracellular protozoa such as T. vaginalis by activated macrophages is also mediated by NO [49] and protozoa degrades NO as a new pathogenic mechanism of action in vitro [86]. These results suggest that RNI radicals may have a role in limiting $T$. vaginalis infection in asymptomatic women [87].

\section{Giardia sp.}

Giardia intestinalis produce NO and display NOS activity [85]. NO and arginine was detected as central components in a novel cross-talk between a luminal pathogen G. lamblia and host intestinal epithelium [88]. Moreover, NO accounts for trophozoite killing and this effect is not mediated by peroxynitrite [44]. Neuronal NOS is necessary for elimination of G. lamblia infections in mice [89], however serum levels of NO increased only in some cases during Giardiasis [90].

\section{Entamoeba sp.}

Trophozoites of Entamoeba histolytica produce NO in culture by activated macrophages as a major cytotoxic molecule against $E$. histolytica trophozoites [91]. NO produced and that $\mathrm{O}_{2}$ - and $\mathrm{H}_{2} \mathrm{O}_{2}$ may be cofactors for the NO effector molecules [92-93]. NO production and iNOS mRNA expression were confirmed in experimental hepatic amoebiasis [94] and during development of liver abscess in hamster inoculated with E. histolytica [95]. Unlike in mice, amoebic liver abscess in hamsters [96] and in humans [97] is due to an excess in NO production. NO is involved in the neutrophil and macrophage killing of the E. histolytica [98]. Although, E. histolytica selectively induces macrophage by modulating iNOS and NO, allowing the parasites to survive within the host [99], E. histolytica inhibits NO-mediated amoebicidal activity of macrophages by consuming L-arginine [100]. The resistance of the mice probably lies in non-specific immune responses, among which the neutrophils activation and NO production may be important amoebicide factors [101]. TNF- $\alpha$ and TGF- $\beta$ are demonstrated to be associated with NO-dependent macrophage cytotoxicity against $E$. histolytica [92].

\section{NO and Related Molecules in Helminthic Infections}

NO possesses antiparasitic effects on both protozoa and metazoa in definitive and intermediate hosts [51]. Several groups have previously presented evidence for NOS activity and immunoreactivity in several parasitic platyhelminthes, indicating that NO release may play an important role in helminth physiology [102]. Most helminthes induce inflammation in the host associated with NO production through somatic and excretory-secretory antigens of adult worm and larvae [103]. An association was hypothesized that helminthes may induce protection through immunoglobulin $\mathrm{E}$ (IgE) and the CD23/NO pathway [104]. Our data imply that NO production in host defense against the extracellular parasite is probably in response to an IFN-ã activating signal. Concomitant enhanced levels of IFN-ã and nitrite represent useful indicators of the clinical aggressiveness of hydatidosis [105].

\section{Nematodes $s p$.}

NO is produced in several nematodes including Ascaris suum [106], Brugia malayi and Acanthocheilonema viteae [107]. A potential role for NO as a neurotransmitter at the neuromuscular junction was observed in A. suum [108]. In addition, an inhibitory effect on nematode somatic muscle is mediated by NO [109]. Although, the biochemical presence of NOS activity is indicated in A. suum tissue [110] and in B. malayi, NOS may play a role in developmental signaling [111].

\section{Toxocara sp.}

Antigens of T. canis is reported to produces $\mathrm{NO}$ and $\mathrm{PGE}_{2}$ in vitro [112]. In vivo production of NO during Toxocara canis infection causes direct host damages and it is strongly related to the oxidative stress and larval NO is effective in migration [113]. A potential therapeutic strategy is presented for experimental granulomatous hepatitis caused by $T$. canis in mice through manipulation of iNOS expression [114]. In vivo inhibition of iNOS decreases lung injury induced by this nematode in infected rats [112]. Cytokines and iNOS is involved in the cerebral pathology during infection with $T$. canis [115], whereas, iNOS inhibition can protect the brains of infected mice from damage [116].

\section{Schistosoma sp.}

NO and NOS was significantly involved in different stages of human schistosomiasis including Schistosoma mansoni, [117], S. haematobium [118] and S. japonicum infections [119]. Although, S. japonicum infection induce the expression of iNOS in a time-dependent manner in the liver of the host, the eggs may be the main factor in this induction [119]. There are controversial reports about NOS activity in murine schistosomiasis; NOS inhibits egg-induced granuloma formation in the mouse liver [120], however NOS activity increased during granulomatous inflammation in the colon and caecum of pigs infected with S. japonicum [121] and its inhibition reduces liver injury in mice [122]. An important 
regulatory role for the iNOS biosynthetic pathway as a critical determinant in the pathogenesis of granuloma was observed [123].

\section{Fasciola sp.}

The levels of both superoxide and NO radicals were reported to be significantly higher in patients with Fasciola hepatica in compare with control group, indicating these radicals may have a role in the immunity against human [124] and rodent infections [125]. Some parasiticidal effects of peroxynitrite was reported on bovine liver flukes including $F$. hepatica and Dicrocoelium dendriticum in vitro [126]. The mechanism of cytotoxicity was dependent on the production of NO and required attachment of effector cells to the newly excysted juvenile liver $F$. hepatica tegument in infected hosts [127]. Trematoda immune suppression, decreases NO production by host peritoneal cells and it is one of the strategies of the parasite to avoid the potential killing effect of NO during peritoneal migration [128].

\section{Echinoccocus sp.}

The results of experimental infection with Echinococcus granulosus, E. multilocularis and E. alveolaris showed that serum NO level was significantly increased, which is needed for in vitro killing of protoscoleces [117, 129, 130]. The NO elevation on hepatic pathological lesions of disease showed a marked reduction of granuloma size with absence of concentric fibrosis [117]. Controversially, some researchers reported NO-mediated immunosuppression following murine Echinococcus infection [131] and the high level of NO production during chronic infection, which contribute more to immunosuppression than to limitation of parasite growth [132]. Results indicated that IFN-ã mediated iNOS is induced as one of host defense mechanism against human $E$. granulosus infection [133]. Collectively, the data indicated that NO concentration correlate with IFN- $\gamma$ levels, and overall suggest that their production together play a role in the host defense mechanisms in human hydatidosis [134].

\section{Taenia sp.}

Macrophage activation and NO production are effector mechanisms that importantly contribute in host resistance to Taenia crassiceps infection [135]. NO contributes directly to a component of inhibitory transmission in guinea-pig T. coli [136], therefore a possible role of L-arginine-NO pathway is presented in the modulation of transmission in this guineapig cestoda [137]. In addition, the source and role of basal NO in vitro in proximal segments of another species of taenia ( $T$. caeci) in guinea pig was also indicated [138].

\section{Conclusive Remarks}

Taken together, the data provided by researchers highlight the fact that NO and/or its related molecules are involved in many infectious diseases, but the involvement is not independent of other immune events. It is indicated that NO is an important, but possibly not essential contributor in the control of acute phase of parasitic infections. Although, the protective immune responses against microorganisms are multifactorial, the final effector molecules that mediate organism death are not known, NOS, NO, and RNI have been significantly implicated. It is concluded that NO is only part of an immunopathological chain against infection and the antimicrobial function did not relate only to NO action, therefore a combination of $\mathrm{NO}$ and other immune factors is required to resolve pathogens. In summary, it is highlighted the complexity and variation of NO-released by different NOS isoforms in parasitic infections and discussed that NOS activation could have both pro- and anti-inflammatory effects. Moreover, it is emphasised here that iNOS-derived NO may have an extrafunctional qualification to overcome pathogenic parasites. It is possible that these effects could be critically dependent on the type and concentration of NO generated. Finally, it is still unclear whether NOS inhibition would be a good therapeutic target in parasitic infections. It is suggested that the detrimental effect of NOS is related to the L-arginine and NO concentrations, because NO at high concentration has a clear anti-inflammatory effect [139-142]. Thus, activation of NO could be a potential therapeutic strategy to suppress parasitic infections [143-145]. Nevertheless, the functional role of NO and NOS isoforms in the immune responses of host against the majority of parasites is still highly controversial. Therefore, the involvement of NO and its up / downstream molecules in parasitic infections is cuurently under debate and it is still required more investigations [146-147].

\section{Acknowledgments}

I would like to express my gratitude to Dr. Mojgan Mohammadi from Department of Immunology, Kerman University of Medical Sciences for review the manuscript and constructive comments.

\section{References}

1. Kroncke KD, Fehsel K, Kolb-Bachofen V. Nitric oxide: cytotoxicity versus cytoprotection: how, why, when, and where? Nitric Oxide: Biology and Chemistry 1997;1:107120 .

2. Lancaster JRJ. A tutorial on the diffusibility and reactivity of free nitric oxide. Nitric Oxide 1997;1:18-30.

3. Nahrevanian H, Dascombe MJ. Reactive nitrogen intermediate (RNI) levels inside and outside Plasmodium infected red blood cells in murine malaria, J Trop Med Parasitol 2003;26(1):13-19.

4. Ellis G, Adatia I, Yazdanpanah M, Makela SK. Nitrite and nitrate analyses: a clinical biochemistry perspective. Clin Biochem 1998;31:195-220.

5. Clark IA, Rockett KA, Cowden WB. Possible central role of nitric oxide in conditions clinically similar to cerebral malaria. Lancet 1992;340:894-96.

6. Nahrevanian H, Dascombe MJ. Nitric oxide and reactive nitrogen intermediates in lethal and nonlethal strains of murine malaria. Parasite Immunol 2001;23:491-501.

7. Nahrevanian H, Dascombe MJ. Expression of inducible nitric oxide synthase (iNOS) mRNA in target organs of lethal and nonlethal strains of murine malaria, Parasite Immunol 2002;24(910):471-78. 
8. Nahrevanian H, Dascombe MJ. Simultaneous increases in immune competent cells and nitric oxide in the spleen during Plasmodium berghei infection in mice. J Microbiol Immunol Infec 2006;39(1):11-17.

9. Nahrevanian H, Gholizadeh SJ, Farahmand M, Aghighi Z, Assmar M, Abolhassani M. Reactive nitrogen intermediate production and tolerance variability in different mouse strains after in vivo treatment with lipopolysaccharide from Salmonella abortus equi. J Microbiol Immunol Infec 2005;38(3):164-68.

10. Nahrevanian H, Gholizadeh J, Farahmand M, Assmar M, Sharifi K, Ayatollahi Mousavi SA, Abolhassani M. Nitric oxide induction as a novel immunoepidemiological target in malaria-infected patients from endemic areas of Islamic Republic of Iran. Scand J Clin Lab Invest 2006;66(3):201-10.

11. Dascombe MJ, Nahrevanian H. Pharmacological assessment of the role of nitric oxide in mice infected with lethal and nonlethal species of malaria, Parasite Immunol 2003;25(3):149-59.

12. Nussler AK, Di Silvio M, Billiar TR, Hoffman RA, Geller DA, Selby R, Madariaga J, Simmons RL. Stimulation of the nitric oxide synthase pathway in human hepatocytes by cytokines and endotoxin. J Exp Med 1992;176:261-64.

13. Nahrevanian H. Nitric oxide involvement during malaria infection; Immunological concepts, mechanisms and complexities; A novel review. J Trop Med Parasitol, 2004;27(2):93-101.

14. Burdon MG, Butler AR, Renton LM. A study of antibacterial activity of nitric oxide donor compounds. In: The biology of nitric oxide, ed. by Moncada S, Stamler J, Gross S, Higgs EA. Portland Press Ltd., London 1996; p.170.

15. Motard A, Landau I, Nussler A, Grau G, Baccam D, Mazier D, Targett GA. The role of reactive nitrogen intermediates in modulation of gametocyte infectivity of rodent malaria parasites. Parasite Immunol 1993;15:21-26.

16. Liew FY, Li Y, Millott S. Tumor necrosis factor-a synergizes with IFN-gamma in mediating killing of Leishmania major through the induction of nitric oxide. J Immunol 1990;145:4306-310.

17. Adams B, Hibbs JB, Taintor RR, Krahenbuhl JL. Microbiostatic effect of murine activated macrophages for Toxoplasma gondii. Role for synthesis of inorganic nitrogen oxides from L-arginine. J Immunol 1990;144:2725-729.

18. Vincendeau P, Dalouede S. Macrophages cytostatic effect on Trypanosoma musculi involves an L-arginine-dependent mechanism. J Immunol 1991;146:4338-343.

19. Gazzinelli RT, Oswald IP, Heiny S, James SL, Sher A. The microbicidal activity of interferon treated macrophages against Trypanosoma cruzi involves an L-arginine-dependent, nitrogen oxide-mediated mechanism inhibitable by interleukin-10 and transforming growth factor-b. Eur J Immunol 1992;22:2501506 .

20. Adams LB, Franzblau SG, Vavrin V, Hibbs JRJ, Krahenbuhl JL. Larginine-dependent macrophage effector functions inhibit metabolic activity of Mycobacterium leprae. J Immunol 1991; $147: 1642-646$.

21. Denis M. Tumor necrosis factor and granulocytes macrophagescolony stimulating factor stimulate human macrophages to restrict growth of virulent Mycobacterium avium and to kill avirulent M. avium: Killing effector mechanism depends on the generation of reactive nitrogen intermediates. J Leuk Biol 1991;49:380-87.

22. Cenci E, Romani L, Mencacci A, Spaccapelo R, Schiabbella E, Paccetti P, Bistoni F. Interleukin-4 and interleukin-10 inhibit nitric oxide-dependent macrophage killing of Candida albicans. Eur J Immunol 1993;23:1034-38.

23. Gunasegaran K, Xie Q-W, Buller RM, Nathan C, Duarte C, MacMicking JD. Inhibition of viral replication by interferong-induced nitric oxide synthase. Science 1993;261:1445-447.

24. Fierro IM, Barja-Fidalgo C, Cunha FQ, Ferreira SH. The involvement of nitric oxide in the anti-Candida albicans activity of rat neutrophils. Immunol 1996;89:295-300.
25. Malawista SE, Montgomery RR, Van Blaricom G. Evidence for reactive nitrogen intermediates in killing of Staphylococci by human neutrophil cytoplasts. A new microbicidal pathway for polymorphonuclear leukocytes. J Clin Invest 1992;90:63136.

26. Pimenta PFP, Dos Santos MAV, De Souza W. Fine structure and cytochemistry of the interaction between Leishmania mexicana amazonensis and rat neutrophils and eosinophils. J Submicrosc Cytol 1987; 19:387-95.

27. Pearson RD, Uydess IL, Chapman SW, Steigbigel RT. Interaction of human eosinophils with Leishmania donovani. Ann Trop Med Parasitol 1987;81:735-39.

28. Oliveira SHP, Fonseca SG, Romao PRT, Ferreira SH, Cunha FQ. Nitric Oxide Mediates the Microbicidal Activity of Eosinophils. Mem Inst Oswaldo Cruz, Rio de Janeiro, 1997;92(Suppl.II):23335.

29. Mayer B. Structure and function of nitric oxide synthase. Nitric Oxide: Biology and Chemistry 1998;2:390-91.

30. Xu WM, Liu LZ. Nitric oxide: from a mysterious labile factor to the molecule of the Nobel Prize. Recent progress in nitric oxide research. Cell Res 1998;8:251-58.

31. Baudouin JE, Tachon P. Characterization of a constitutive nitric oxide synthase from normal human keratinocytes. In: The biology of nitric oxide, ed. by Moncada S, Stamler J, Gross S, Higgs EA. Portland Press Ltd., London 1996; p.54.

32. Babu BR, Griffith OW. Design of isoform-selective inhibitors of nitric oxide synthase. Curr Opin Chem Biol 1998;2:491-500.

33. Bogdan C, Rollinghoff M, Diefenbach A. Reactive oxygen and reactive nitrogen intermediates in innate and specific immunity. Curr Opin Immunol 2000;12:64-76.

34. Bogdan C, Rollinghoff M, Diefenbach A. The role of nitric oxide in innate immunity. Immunol Rev 2000;173:17-26.

35. Park CS, Lee HS, Lee HY, Krishna G. An unprocessed pseudogene of inducible nitric oxide synthase gene in human. Nitric Oxide 1997;1:294-300.

36. Favre N, Ryffel B, Rudin W. Parasite killing in murine malaria does not require nitric oxide production. Parasitol 1999;118:13943.

37. Favre N, Ryffel B, Rudin W. The development of murine cerebral malaria does not require nitric oxide production. Parasitol 1999;118:135-38.

38. Dugbartey AT, Spellacy FJ, Dugbartey MT. Somatosensory discrimination deficits following pediatric cerebral malaria. Am J Trop Med Hyg 1998;59:393-96.

39. Granger DL, Hibbs JB. High-output nitric oxide: weapon against infection? Trends Microbiol 1996;4:46-47.

40. Clark IA, al-Yaman FM, Cowden WB, Rockett KA. Does malarial tolerance, through nitric oxide, explain the low incidence of autoimmune disease in tropical Africa? Lancet 1996;348:1492494.

41. Roitt IM, Brostoff J, Male D. Immunology. 5th edition Mosby Publication, London, 1998;pp.132-133, 235, 246, 247,314.

42. Mellouk S, Green SJ, Nacy CA, Hoffman SL. IFN-gamma inhibits development of Plasmodium berghei exoerythrocytic stages in hepatocytes by an L-arginine-dependent effector mechanism. J Immunol 1991;146:3971-976.

43. Liew FY. Regulation of nitric oxide synthase in macrophages. In: The biology of nitric oxide: 2 Enzymology,Biochemistry and Immunology, ed. by Moncada, S., Stamler, J., Gross, S. \& Higgs, E.A. Portland Press, London, UK, 1992;pp.223-29.

44. Fernandes PD, Assreuy J. Role of nitric oxide and superoxide in Giardia lamblia killing. Braz J Med Biol Res 1997;30:93-99.

45. Augusto O, Linares E, Giorgio S. Possible roles of nitric oxide and peroxynitrite in murine leishmaniasis. Braz J Med Biol Res 1996;29:853-862.

46. Taylor-Robinson AW. Nitric oxide can be released as well as scavenged by haemoglobin: relevance to its antimalarial activity. Parasite Immunol 1998;20:49-50. 
47. Mannick EE, Oliver PD, Sadowska-Krowicka H, Miller MJS. Inhibition of inducible nitric oxide synthase reverse endotoxin tolerance in cultured macrophages. In: The biology of nitric oxide, ed. by Moncada, S., Stamler, J., Gross, S. \& Higgs, E.A. Portland Press Ltd., London, 1996;p.144.

48. Haswell-Elkins M, Satarug S, Sithithaworn P, Mairiang E, Mairiang P, Elkins D. Nitrate excretion and parasite-specific $T$ lymphocyte responses of humans infected with the liver fluke, Opisthorchis viverrini. In: The biology of nitric oxide: 1 Physiological and clinical aspects, ed. by Moncada, S., Marletta, M.A., Hibbs, JR.J.B. \& Higgs, E.A. Portland Press, London, UK, 1992;p.380.

49. Gradoni L, Ascenzi P. Nitric oxide and anti-protozoan chemotherapy. Parassitologia. 2004;46(1-2):101-3.

50. Stempin CC, Cerban FM. Macrophages and arginase induction as a mechanism for parasite escape. Medicina (B Aires). 2007;67(6 Pt 2):737-46.

51. Ascenzi P, Fasano M, Gradoni L. Do hemoglobin and hemocyanin impair schistosoma killing by no? IUBMB Life. 2002;53(6):287-8.

52. Zafra R, Jaber JR, Pérez-Ecija RA, Barragán A, Martínez-Moreno A, Pérez J. High iNOS expression in macrophages in canine leishmaniasis is associated with low intracellular parasite burden. Vet Immunol Immunopathol. 2008, 15;123(3-4):353-9.

53. Panaro MA, Brandonisio O, de Caprariis D, Cavallo P, Cianciulli A, Mitolo V, Otranto D. Canine leishmaniasis in Southern Italy: a role for nitric oxide released from activated macrophages in asymptomatic infection? Parasit Vectors. 2008; 9;1(1):10.

54. Valdez CA, Saavedra JE, Showalter BM, Davies KM, Wilde TC, Citro ML, Barchi JJ Jr, Deschamps JR, Parrish D, El-Gayar S, Schleicher U, Bogdan C, Keefer LK. Hydrolytic reactivity trends among potential prodrugs of the O2-glycosylated diazeniumdiolate family. Targeting nitric oxide to macrophages for antileishmanial activity. J Med Chem. 2008; 10;51(13):3961-70.

55. Soares-Bezerra RJ, da Silva EF, Echevarria A, Gomes-da-Silva L, Cysne-Finkelstein L, Monteiro FP, Leon LL, Genestra M. Effect of mesoionic 4-phenyl-5-(cinnamoyl)-1,3,4thiadiazolium-2-phenylamine chloride derivative salts on the activities of the nitric oxide synthase and arginase of Leishmania amazonensis. J Enzyme Inhib Med Chem. 2008;23(3):32833.

56. Ferreira AS, de Souza MA, Barbosa NR, da Silva SS. Leishmania amazonensis: xylitol as inhibitor of macrophage infection and stimulator of macrophage nitric oxide production. Exp Parasitol. 2008;119(1):74-9.

57. Linares E, Giorgio S, Augusto O. Inhibition of in vivo leishmanicidal mechanisms by tempol: nitric oxide downregulation and oxidant scavenging. Free Radic Biol Med. 2008;44(8):1668-76.

58. Wang QH, Liu YJ, Liu J, Chen G, Zheng W, Wang JC, Cao YM. Plasmodium yoelii: Assessment of production and role of nitric oxide during the early stages of infection in susceptible and resistant mice. Exp Parasitol. 2009;121(3):268-73.

59. Koka S, Lang C, Niemoeller OM, Boini KM, Nicolay JP, Huber SM, Lang F. Influence of NO synthase inhibitor L-NAME on parasitemia and survival of Plasmodium berghei infected mice. Cell Physiol Biochem. 2008;21(5-6):481-8.

60. Safeukui I, Vatan R, Dethoua M, Agbo H, Haumont G, Moynet D, Malvy D, Vincendeau P, Mossalayi D, Millet P. A role of IgE and CD23/NO immune pathway in age-related resistance of Lewis rats to Plasmodium berghei Anka? Microbes Infect. 2008; 10(12-13):1411-6.

61. Yeo TW, Rooslamiati I, Gitawati R, Tjitra E, Lampah DA, Kenangalem E, McNeil YR, Price RN, Anstey NM, Duffull SB. Pharmacokinetics of L-arginine in adults with moderately severe malaria. Antimicrob Agents Chemother. 2008;52(12):4381-7.
62. Cramer JP, Nüssler AK, Ehrhardt S, Burkhardt J, Otchwemah RN, Zanger P, Dietz E, Gellert S, Bienzle U, Mockenhaupt FP. Agedependent effect of plasma nitric oxide on parasite density in Ghanaian children with severe malaria. Trop Med Int Health. 2005;10(7):672-80.

63. Sobolewski P, Gramaglia I, Frangos J, Intaglietta M, van der Heyde HC. Nitric oxide bioavailability in malaria. Trends Parasitol. 2005;21(9):415-22.

64. Gramaglia I, Sobolewski P, Meays D, Contreras R, Nolan JP, Frangos JA, Intaglietta $M$, van der Heyde HC. Low nitric oxide bioavailability contributes to the genesis of experimental cerebral malaria. Nat Med. 2006;12(12):1417-22.

65. Ostera G, Tokumasu F, Oliveira F, Sa J, Furuya T, Teixeira C, Dvorak J. Plasmodium falciparum: food vacuole localization of nitric oxide-derived species in intraerythrocytic stages of the malaria parasite. Exp Parasitol. 2008;120(1):29-38.

66. Hunt NH, Golenser J, Chan-Ling T, Parekh S, Rae C, Potter S, Medana IM, Miu J, Ball HJ. Immunopathogenesis of cerebral malaria. Int J Parasitol. 2006;36(5):569-82.

67. Sobolewski P, Gramaglia I, Frangos JA, Intaglietta M, van der Heyde $\mathrm{H}$. Plasmodium berghei resists killing by reactive oxygen species. Infect Immun. 2005;73(10):6704-10.

68. Guillermo LV, DaMatta RA. Nitric oxide inhibition after Toxoplasma gondii infection of chicken macrophage cell lines. Poult Sci. 2004;83(5):776-82.

69. Nishikawa Y, Kawase O, Vielemeyer O, Suzuki H, Joiner KA, Xuan $\mathrm{X}$, Nagasawa H. Toxoplasma gondii infection induces apoptosis in noninfected macrophages: role of nitric oxide and other soluble factors. Parasite Immunol. 2007;29(7):375-85.

70. Gutierrez-Escobar AJ, Arenas AF, Villoria-Guerrero Y, PadillaLondoño JM, Gómez-Marin JE. Toxoplasma gondii: molecular cloning and characterization of a nitric oxide synthase-like protein. Exp Parasitol. 2008;119(3):358-63.

71. Kang KM, Lee GS, Lee JH, Choi IW, Shin DW, Lee YH. Effects of iNOS inhibitor on IFN-gamma production and apoptosis of splenocytes in genetically different strains of mice infected with Toxoplasma gondii. Korean J Parasitol. 2004;42(4):17583.

72. Machado FS, Souto JT, Rossi MA, Esper L, Tanowitz HB, Aliberti J, Silva JS. Nitric oxide synthase-2 modulates chemokine production by Trypanosoma cruzi-infected cardiac myocytes. Microbes Infect. 2008;10(14-15):1558-66.

73. Ribeiro DA, Calvi SA, Picka MM, Persi E, de Carvalho TB, Caetano PK, Nagoshi LR, Lima CR, Machado JM, Salvadori DM. DNA damage and nitric oxide synthesis in experimentally infected Balb/c mice with Trypanosoma cruzi. Exp Parasitol. 2007;116(3):296-301.

74. Nishimura K, Yagi M, Ohnishi Y, Yamasaki S. Cytokine and nitric oxide production by Trypanosoma brucei infection in rats fed polyamine-deficient chow. J Parasitol. 2008;94(1):107-13.

75. Vieira PM, Francisco AF, de Souza SM, Malaquias LC, Reis AB, Giunchetti RC, Veloso VM, de Lana M, Tafuri WL, Carneiro CM. Trypanosoma cruzi: Serum levels of nitric oxide and expression of inducible nitric oxide synthase in myocardium and spleen of dogs in the acute stage of infection with metacyclic or blood trypomastigotes. Exp Parasitol. 2009;121(1):76-82.

76. Guiñazú N, Pellegrini A, Carrera-Silva EA, Aoki MP, Cabanillas AM, Gìronés N, Fresno M, Cano R, Gea S. Immunisation with a major Trypanosoma cruzi antigen promotes proinflammatory cytokines, nitric oxide production and increases TLR2 expression. Int J Parasitol. 2007,37(11):1243-54.

77. Ny L, Li H, Mukherjee S, Persson K, Holmqvist B, Zhao D, Shtutin V, Huang H, Weiss LM, Machado FS, Factor SM, Chan J, Tanowitz HB, Jelicks LA. A magnetic resonance imaging study of intestinal dilation in Trypanosoma cruzi-infected mice deficient in nitric oxide synthase. Am J Trop Med Hyg. 2008;79(5):760-7. 
78. Gookin JL, Allen J, Chiang S, Duckett L, Armstrong MU.Local peroxynitrite formation contributes to early control of Cryptosporidium parvum infection. Infect Immun. 2005;73(7):3929-36.

79. Gookin JL, Chiang S, Allen J, Armstrong MU, Stauffer SH, Finnegan C, Murtaugh MP. NF-kappaB-mediated expression of iNOS promotes epithelial defense against infection by Cryptosporidium parvum in neonatal piglets. Am J Physiol Gastrointest Liver Physiol. 2006;290(1):G164-74.

80. Leitch GJ, He Q. Arginine-derived nitric oxide reduces fecal oocyst shedding in nude mice infected with Cryptosporidium parvum. Infect Immun. 1994;62(11):5173-6.

81. Chen YF, Qin YH, Zheng LL, Dai XD, Ren YX, Nie DP, Cui Y. Experimental treatment using combined Fructus psoraleae and dihydroartemisinin in mouse cryptosporidiosis. Zhongguo Ji Sheng Chong Xue Yu Ji Sheng Chong Bing Za Zhi. 2008;26(1):67-9.

82. Gookin JL, Duckett LL, Armstrong MU, Stauffer SH, Finnegan CP, Murtaugh MP, Argenzio RA. Nitric oxide synthase stimulates prostaglandin synthesis and barrier function in C. parvuminfected porcine ileum. Am J Physiol Gastrointest Liver Physiol. 2004;287(3):G571-81.

83. Leitch GJ, He Q. Reactive nitrogen and oxygen species ameliorate experimental cryptosporidiosis in the neonatal BALB/c mouse model. Infect Immun. 1999;67(11):5885-91.

84. Park GC, Ryu JS, Min DY. The role of nitric oxide as an effector of macrophage-mediated cytotoxicity against Trichomonas vaginalis. Korean J Parasitol. 1997;35(3):189-95.

85. Harris KM, Goldberg B, Biagini GA, Lloyd D. Trichomonas vaginalis and Giardia intestinalis produce nitric oxide and display NOsynthase activity. J Eukaryot Microbiol. 2006;53 Suppl 1:S1823 .

86. Sarti P, Fiori PL, Forte E, Rappelli P, Teixeira M, Mastronicola D, Sanciu G, Giuffré A, Brunori M. Trichomonas vaginalis degrades nitric oxide and expresses a flavorubredoxin- like protein: a new pathogenic mechanism? Cell Mol Life Sci. 2004;61(5):61823.

87. Yadav M, Dubey ML, Gupta I, Malla N. Nitric oxide radicals in leucocytes and vaginal washes of Trichomonas vaginalis infected symptomatic and asymptomatic women. Parasitology. 2006;132(Pt 3):339-43.

88. Eckmann L, Laurent F, Langford TD, Hetsko ML, Smith JR, Kagnoff MF, Gillin FD. Nitric oxide production by human intestinal epithelial cells and competition for arginine as potential determinants of host defense against the lumendwelling pathogen Giardia lamblia. J Immunol. 2000;164(3):1478-87.

89. Li E, Zhou P, Singer SM. Neuronal nitric oxide synthase is necessary for elimination of Giardia lamblia infections in mice. J Immunol. 2006;176(1):516-21.

90. Bayraktar MR, Mehmet N, Durmaz R. Serum cytokine changes in Turkish children infected with Giardia lamblia with and without allergy: Effect of metronidazole treatment. Acta Trop. 2005;95(2):116-22.

91. Hernández-Campos ME, Campos-Rodríguez R, Tsutsumi V, Shibayama M, García-Latorre E, Castillo-Henkel C, ValenciaHernández I. Nitric oxide synthase in Entamoeba histolytica: its effect on rat aortic rings. Exp Parasitol. 2003;104(3-4):8795.

92. Lin JY, Seguin R, Keller K, Chadee K. Transforming growth factorbeta 1 primes macrophages for enhanced expression of the nitric oxide synthase gene for nitric oxide-dependent cytotoxicity against Entamoeba histolytica. Immunology. 1995;85(3):400-7.

93. Lin JY, Chadee K. Macrophage cytotoxicity against Entamoeba histolytica trophozoites is mediated by nitric oxide from Larginine. J Immunol. 1992; 148(12):3999-4005.
94. Pacheco-Yepez J, Campos-Rodríguez R, Ventura-Juárez J, Shibayama M, Martínez-Palomo A, Tsutsumi V. Role of nitric oxide in experimental hepatic amebiasis. Arch Med Res. 1997;28 Spec No:214-6.

95. Ramírez-Emiliano J, González-Hernández A, Arias-Negrete S. Expression of inducible nitric oxide synthase mRNA and nitric oxide production during the development of liver abscess in hamster inoculated with Entamoeba histolytica. Curr Microbiol. 2005;50(6):299-308.

96. Pacheco-Yépez J, Campos-Rodríguez R, Shibayama M, VenturaJuárez J, Serrano-Luna J, Tsutsumi V. Entamoeba histolytica: production of nitric oxide and in situ activity of NADPH diaphorase in amebic liver abscess of hamsters. Parasitol Res. 2001;87(1):49-56.

97. Ramirez-Emiliano J, Flores-Villavicencio LL, Segovia J, AriasNegrete S.Nitric oxide participation during amoebic liver abscess development. Medicina (B Aires). 2007;67(2):167-76.

98. Siman-Tov R, Ankri S. Nitric oxide inhibits cysteine proteinases and alcohol dehydrogenase 2 of Entamoeba histolytica. Parasitol Res. 2003;89(2):146-9.

99. Wang W, Keller K, Chadee K. Entamoeba histolytica modulates the nitric oxide synthase gene and nitric oxide production by macrophages for cytotoxicity against amoebae and tumour cells. Immunology. 1994;83(4):601-10.

100. Elnekave K, Siman-Tov R, Ankri S. Consumption of L-arginine mediated by Entamoeba histolytica L-arginase (EhArg) inhibits amoebicidal activity and nitric oxide production by activated macrophages. Parasite Immunol. 2003;25(11-12):597-608.

101. Jarillo-Luna RA, Campos-Rodríguez R, Tsutsumi V. Entamoeba histolytica: immunohistochemical study of hepatic amoebiasis in mouse. Neutrophils and nitric oxide as possible factors of resistance. Exp Parasitol. 2002;101(1):40-56.

102. Kohn AB, Lea JM, Moroz LL, Greenberg RM. Schistosoma mansoni: use of a fluorescent indicator to detect nitric oxide and related species in living parasites. Exp Parasitol. 2006;113(2):130-3.

103. Andrade MA, Siles-Lucas M, Espinoza E, Pérez Arellano JL, Gottstein B, Muro A. Echinococcus multilocularis laminatedlayer components and the E14t 14-3-3 recombinant protein decrease NO production by activated rat macrophages in vitro. Nitric Oxide. 2004;10(3):150-5.

104. Nacher M, Singhasivanon P, Traore B, Vannaphan S, Gay F, Chindanond D, Franetich JF, Mazier D, Looareesuwan S. Helminth infections are associated with protection from cerebral malaria and increased nitrogen derivatives concentrations in Thailand. Am J Trop Med Hyg. 2002;66(3):304-9.

105. Ait Aissa S, Amri M, Bouteldja R, Wietzerbin J, Touil-Boukoffa C. Alterations in interferon-gamma and nitric oxide levels in human echinococcosis. Cell Mol Biol (Noisy-le-grand). 2006; 15;52(1):65-70.

106. Zhu W, Pryor SC, Putnam J, Cadet P, Stefano GB. Opiate alkaloids and nitric oxide production in the nematode Ascaris suum. J Parasitol. 2004;90(1):15-22.

107. Pfarr KM, Qazi S, Fuhrman JA. Nitric oxide synthase in filariae: demonstration of nitric oxide production by embryos in Brugia malayi and Acanthocheilonema viteae. Exp Parasitol. 2001;97(4):205-14.

108. Bascal ZA, Montgomery A, Holden-Dye L, Williams RG, Walker RJ. Histochemical mapping of NADPH diaphorase in the nervous system of the parasitic nematode Ascaris suum. Parasitology. 1995;110 (Pt 5):625-37.

109. Minning DM, Gow AJ, Bonaventura J, Braun R, Dewhirst M, Goldberg DE, Stamler JS. Ascaris haemoglobin is a nitric oxideactivated 'deoxygenase'. Nature. 1999;401(6752):497-502.

110. Bascal ZA, Cunningham JM, Holden-Dye L, O’Shea M, Walker RJ. Characterization of a putative nitric oxide synthase in the neuromuscular system of the parasitic nematode, Ascaris suum. Parasitology. 2001;122(Pt 2):219-31. 
111. Pfarr KM, Fuhrman JA. Brugia malayi: localization of nitric oxide synthase in a lymphatic filariid. Exp Parasitol. 2000;94(2):92-8.

112. Espinoza EY, Pérez-Arellano JL, Carranza C, Collía F, Muro A. In vivo inhibition of inducible nitric oxide synthase decreases lung injury induced by Toxocara canis in experimentally infected rats. Parasite Immunol. 2002;24(11-12):511-20.

113. Demirci C, Gargili A, Kandil A, Cetinkaya H, Uyaner I, Boynuegri $\mathrm{B}$, Gumustas MK. Inhibition of inducible nitric oxide synthase in murine visceral larva migrans: effects on lung and liver damage. Chin J Physiol. 2006;49(6):326-34.

114. Fan CK, Lin YH, Hung CC, Chang SF, Su KE. Enhanced inducible nitric oxide synthase expression and nitrotyrosine accumulation in experimental granulomatous hepatitis caused by Toxocara canis in mice. Parasite Immunol. 2004;26(6-7):273-81.

115. Lin SM, Liao CW, Lin YH, Lee CC, Kao TC, Fan CK. Inducible nitric oxide synthase inhibition influenced granuloma formation with suppressed collagen expression in myositis caused by Toxocara canis in mice. Parasitol Res. 2008;102(4):577-85.

116. Gargili A, Demirci C, Kandil A, Cetinkaya H, Atukeren P, Gümü ${ }^{\circ} a^{\circ}$ MK. In vivo inhibition of inducible nitric oxide and evaluation of the brain tissue damage induced by Toxocara canis larvae in experimentally infected mice. Chin J Physiol. 2004;47(4):189-96.

117. Elwakil HS, Ali NM, Talaat RM, Osman WM. Impact of experimental duel infections with Schistosoma mansoni and Echinoccocus granulosus on hepatic histopathology. J Egypt Soc Parasitol. 2007;37(3 Suppl):1175-88.

118. Salim EI, Morimura K, Menesi A, El-Lity M, Fukushima S, Wanibuchi H. Elevated oxidative stress and DNA damage and repair levels in urinary bladder carcinomas associated with schistosomiasis. Int J Cancer. 2008;123(3):601-8.

119. Long XC, Li YL, Ruppel A. Expression of inducible nitric oxide synthase in the livers of mice infected with Schistosoma japonicum. Zhongguo Ji Sheng Chong Xue Yu Ji Sheng Chong Bing Za Zhi. 2004;22(3):157-9.

120. Hirata M, Hirata K, Kage M, Zhang M, Hara T, Fukuma T. Effect of nitric oxide synthase inhibition on Schistosoma japonicum egg-induced granuloma formation in the mouse liver. Parasite Immunol. 2001;23(6):281-9.

121. Balemba OB, Mortensen K, Semuguruka WD, Hay-Schmidt A, Johansen MV, Dantzer V. Neuronal nitric oxide synthase activity is increased during granulomatous inflammation in the colon and caecum of pigs infected with Schistosoma japonicum. Auton Neurosci. 2002;99(1):1-12.

122. Abdallahi OM, Bensalem H, Diagana M, De Reggi M, Gharib B. Inhibition of nitric oxide synthase activity reduces liver injury in murine schistosomiasis. Parasitology. 2001;122(Pt 3):309-15.

123. Hesse M, Modolell M, La Flamme AC, Schito M, Fuentes JM, Cheever AW, Pearce EJ, Wynn TA. Differential regulation of nitric oxide synthase- 2 and arginase- 1 by type 1 /type 2 cytokines in vivo: granulomatous pathology is shaped by the pattern of Larginine metabolism. J Immunol. 2001;167(11):6533-44.

124. Abo-Shousha S, Khalil SS, Rashwan EA. Oxygen free radical and nitric oxide production in single or combined human schistosomiasis and fascioliasis. J Egypt Soc Parasitol. 1999;29(1):149-56.

125. Sibille P, Tliba O, Boulard C. Early and transient cytotoxic response of peritoneal cells from Fasciola hepatica-infected rats. Vet Res. 2004;35(5):573-84.

126. Sadeghi-Hashjin G, Naem S. Parasiticidal effects of peroxynitrite on ovine liver flukes in vitro. J Helminthol. 2001;75(1):73-6.

127. Piedrafita D, Parsons JC, Sandeman RM, Wood PR, Estuningsih SE, Partoutomo S, Spithill TW. Antibody-dependent cellmediated cytotoxicity to newly excysted juvenile Fasciola hepatica in vitro is mediated by reactive nitrogen intermediates. Parasite Immunol. 2001;23(9):473-82.

128. Cervi L, Rossi G, Cejas H, Masih DT. Fasciola hepatica-induced immune suppression of spleen mononuclear cell proliferation: role of nitric oxide. Clin Immunol Immunopathol. 1998;87(2):145-54.
129. Kanazawa T, Asahi H, Hata H, Mochida K, Kagei N, Stadecker MJ. Arginine-dependent generation of reactive nitrogen intermediates is instrumental in the in vitro killing of protoscoleces of Echinococcus multilocularis by activated macrophages. Parasite Immunol. 1993;15(11):619-23.

130. Li FR, Shi YE, Shi DZ, Vuitton DA, Craig PS. Kinetic analysis of cytokines and immunoglobulin $\mathrm{G}$ subclass in BALB/c mice infected with Echinococcus alveolaris. Zhongguo Ji Sheng Chong Xue Yu Ji Sheng Chong Bing Za Zhi. 2003;21(6):357-60.

131. Dai WJ, Gottstein B. Nitric oxide-mediated immunosuppression following murine Echinococcus multilocularis infection. Immunology. 1999;97(1):107-16.

132. Dai WJ, Waldvogel A, Jungi T, Stettler M, Gottstein B. Inducible nitric oxide synthase deficiency in mice increases resistance to chronic infection with Echinococcus multilocularis. Immunology. 2003;108(2):238-44.

133. Amri M, Aissa SA, Belguendouz H, Mezioug D, Touil-Boukoffa C. In vitro antihydatic action of IFN-gamma is dependent on the nitric oxide pathway. J Interferon Cytokine Res. 2007;27(9):781-7.

134. Touil-Boukoffa C, Bauvois B, Sancéau J, Hamrioui B, Wietzerbin J. Production of nitric oxide (NO) in human hydatidosis: relationship between nitrite production and interferon-gamma levels. Biochimie. 1998;80(8-9):739-44.

135. Alonso-Trujillo J, Rivera-Montoya I, Rodríguez-Sosa M, Terrazas LI. Nitric oxide contributes to host resistance against experimental Taenia crassiceps cysticercosis. Parasitol Res. 2007;100(6):1341-50.

136. Shuttleworth CW, Sweeney KM, Sanders KM. Evidence that nitric oxide acts as an inhibitory neurotransmitter supplying taenia from the guinea-pig caecum. $\mathrm{Br} \mathrm{J}$ Pharmacol. 1999;127(6):1495-501.

137. Knudsen MA, Tøttrup A. A possible role of the L-arginine-nitric oxide pathway in the modulation of cholinergic transmission in the guinea-pig taenia coli. Br J Pharmacol. 1992;107(3):837-41.

138. Caballero-Alomar C, Santos C, Lopez D, Mitjavila MT, PuigParellada P. Sources and implications of basal nitric oxide in spontaneous contractions of guinea pig taenia caeci. Am J Physiol Gastrointest Liver Physiol. 2003;285(4):G747-53.

139. Connelly L, Palacios-Callender M, Ameixa C, Moncada S, Hobbs AJ. Biphasic regulation of NF-kappa B activity underlies the pro- and anti-inflammatory actions of nitric oxide. J Immunol 2001; $166: 3873-881$.

140. Honda K, Kobayashi H, Hataishi R, Hirano S, Fukuyama N, Nakazawa $\mathrm{H}$, Tomita $\mathrm{T}$. Inhaled nitric oxide reduces tyrosine nitration after lipopolysaccharide instillation into lungs of rats. Am J Respir Crit Care Med 1999;160:678-688.

141. Rodriguez D, Keller AC, Faquim-Mauro EL, de Macedo MS, Cunha FQ, Lefort J, Vargaftig BB, Russo M. Bacterial lipopolysaccharide signaling through toll-like receptor 4 suppresses asthma-like responses via nitric oxide synthase 2 activity. J Immunol 2003;171:1001-8.

142. Castro Keller A, Rodriguez D, Russo M. Nitric oxide paradox in asthma. Mem Inst Osw Cruz, Rio de Janeiro 2005;100(Suppl. I):19-23.

143. Nahrevanian H, Gholizadeh J, Farahmand M, Assmar M: Patterns of co-association of C-reactive protein and nitric oxide in malaria in endemic areas of Iran. Mem Inst Osw Cruz, 2008;103(1):39-44.

144. Nahrevanian H: Immune effector mechanisms of nitric oxide pathway in malaria: Cytotoxicity versus cytoprotection. Braz J Infec Dis, 2006;10(4):283-292.

145. Nahrevanian H, Farahmand M, Aghighi Z, Assmar M, Amirkhani A: Pharmacological evaluation of anti-leishmanial activity by in vivo nitric oxide modulation in Balb/c mice infected with Leishmania major MRHO/IR/75/ER; An Iranian strain of cutaneous leishmaniasis. Exp Parasitol, 2007;116(3): 233-240.

146. Nahrevanian H, Amini M: Nitric oxide functions; an emphasis on its diversity in infectious diseases. Iranian J Basic Med Sci, 2009; 11(4): 197-204.

147. Nahrevanian H, Dascombe MJ. The role of nitric oxide and its up/ downstream molecules in malaria: cytotoxic or preventive? Southeast Asian J Trop Med Publ Health 2003;34(S2):44-50. 